\title{
CEDIA method in amphetamine and cannabinoid analysis - potential applications in forensic toxicology blood tests
}

\author{
Urszula Semeniuk ${ }^{\circledR}$, Barbara Potocka-Banaś ${ }^{B}$, Ewa Jasionowicz, Krzysztof Borowiak ${ }^{C}$, Tomasz Janus ${ }^{D}$ \\ Pomeranian Medical University in Szczecin, Department of Clinical Toxicology, Powstańców Wlkp. 72, 70-110 Szczecin, Poland \\ ${ }^{A}$ ORCID: 000-0003-0247-4202; $\quad{ }^{B}$ ORCID: 000-0003-0259-2006; $\quad{ }^{C}$ ORCID: 0000-0002-2526-2686; $\quad{ }^{D}$ ORCID: 0000-0002-2363-2196 \\ $\triangle$ urszula.semeniuk@pum.edu.pl
}

\begin{abstract}
Introduction: Immunoassays are the 1st stage of clinical and forensic toxicology examinations.

The aim of the research was to evaluate the suitability of CEDIA (cloned enzyme donor immmunoassay) for the detection of selected drugs such as amphetamine, tetrahydrocannabinol (THC) metabolite: tetrahydrocanabinolic acid (11-nor-9-carboxy$\Delta$ 9-tetrahydrocannabinol - THC-COOH).

Materials and methods: Blood samples were examined for the presence of the selected psychoactive drugs, similar in effect to alcohol. Whole blood samples were centrifuged, and the obtained plasma was analysed using CEDIA and LC-MS/MS Results: We observed a strong correlation between amphetamine levels measured with CEDIA and the reference technique
\end{abstract}

(LC-MS/MS), and a lack correlation for THC-COOH levels. Cloned enzyme donor immmunoassay did not provide false positive results - positive samples in CEDIA were also positive in LC-MS/ MS, which demonstrated the high specificity of CEDIA.

Conclusions: Considering the high specificity in tests for amphetamine and cannabinoids, CEDIA can be used as a qualitative method in forensic and clinical analysis. This study demonstrates a linearity only for amphetamine detection, which may suggest the need for further verification of the results of other assays offered by the manufacturer. Only serum/plasma can be analysed with CEDIA, which makes this technique unsuitable for highly degraded samples.

Keywords: immunoenzyme techniques; screening methods; CEDIA; LC-MS/MS; psychoactive drugs.

\section{INTRODUCTION}

Immunochemical techniques are widely used in laboratory practice for diagnostic purposes, such as gathering evidence in forensic investigation $[1,2]$. These techniques are used only at the initial stage of analysis (screening test) in forensic examinations, and the results obtained must be confirmed by quantitative reference methods, which currently mainly rely on chromatographic techniques combined with mass spectrometry [3]. Immunochemical techniques are used solely for screening tests because of frequent interferences within the analysed material, of which the most significant are cross-reactions, leading to false positive/negative results $[4,5,6]$. Endogenous substances with a molecular structure similar to the analyte, or various environmental factors causing sample degradation, can bias absorbance measurements and generate false positive results [7]. Due to the specific nature of forensic analyses, any positive result obtained with screening techniques has to be confirmed in repeat analyses of samples using confirmatory techniques. Analyses aimed at the detection of psychoactive substances, including amphetamines and 11-nor-9-carboxy$\Delta$ 9-tetrahydrocannabinol (THC-COOH), are validated with confirmatory tests such as high performance liquid chromatography, high performance liquid chromatography coupled with mass spectrometry, and high performance gas chromatography coupled with mass spectrometry [8]. Even if the results obtained in immunochemical tests are in each case validated, the high reliability of a screening technique used at the early stage of investigation is an unquestioned advantage, because the status of a suspect "under the influence of a narcotic drug" in the legal sense could be assumed with a high probability (high specificity of analytical technique). A screening test has a clear advantage if it provides measurements that strongly correlate with the actual concentration of the analyte in the sample. Therefore, it is crucial to investigate the correlation between concentrations obtained with an immunochemical technique and a reference test, to assess the reliability of quantitative analysis.

The aim of this study was to assess the suitability of cloned enzyme donor immunoassay (CEDIA) for forensic analysis, in terms of the specificity and linearity of this technique. The assessment was based on analysis of samples for the presence of amphetamines and THC-COOH. Amphetamines, tetrahydrocannabinol (THC) and its metabolite: THC-COOH, are among the most frequently detected substances in forensic toxicological tests, which justifies their choice in the present study [9]. The principle of CEDIA immunoassay relies mainly on the use of 2 inactive fragments of $\mid \beta$-galactosidase. Free drug (xenobiotic) molecules present in the analysed sample bind with antibodies and the 2 previously inactive fragments to form an active enzyme molecule, which then binds with the substrate contained in the sample and forms a coloured substrate. The change in absorbance is measured spectrophotometrically $[10,11,12]$ - Figure 1. 
Antibody Free Drug Enzyme-Acceptor Enzyme-Donor

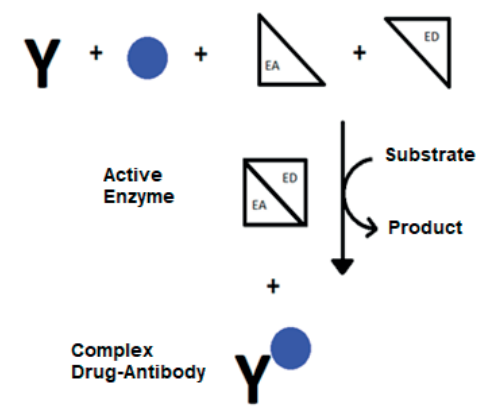

FIGURE 1. Principle of cloned enzyme donor immunoassay method

\section{MATERIALS AND METHODS}

We analysed venous blood samples collected by law enforcement authorities from subjects suspected of committing a crime or traffic offence. The suspected subjects had first been tested by a saliva drug tests. In the case of positive results, blood samples were collected and then delivered to the Clinical and Forensic Toxicology Department of the Pomeranian Medical University of Szczecin to determine the presence of certain psychoactive drugs. Samples of whole blood were provided in standard containers for evidence submission (BD Vacutainer tubes), and were first centrifuged to obtain the plasma, which was immediately analysed using commercially available immunoassay kits for CEDIA. We used kits and reagents for CEDIA ${ }^{\circ}$ Amphetamine Assay and CEDIA $®$ Multi-Level THC Assay (Thermo Scientific), as well as a dedicated calibrator and sets of reference materials. Tests were performed on an Indiko biochemical analyser. Regardless of the analytical result, the samples were analyzed again using a validated reference technique, i.e. high performance liquid chromatography coupled with tandem mass spectrometry: quadrupole-quadrupole-time of flight (QqTOF). These techniques had been developed and validated for the needs of the statutory and commercial activities of our department. Amphetamine was isolated by extraction with chloroform in alkaline conditions, followed by reverse extraction with water mixed with $0.1 \mathrm{HCOOH}$, and after that the aqueous fraction was diluted 1:5 and immediately analyzed. Deuterated methamphetamine-D5 was used as an inhouse reference standard.

Tetrahydrocannabinol and its metabolite, THC-COOH, were isolated by deproteinizing of the tested material with acetonitrile. A sample was centrifuged and the obtained supernatant diluted with deionized water and analysed immediately. Deuterated THC-D3 was used as an in-house reference standard. Analyses were conducted using a Nexera XR liquid chromatograph (Shimadzu) and a TripleTOF 5600+ mass spectrometer, model QqTOF (AB Sciex). Measured values were processed using MultiQuant.

We analysed 141 samples for the presence of amphetamines and 108 samples for the presence of THC-COOH.

\section{RESULTS AND DISCUSSION}

A comparison of values measured with the 2 analytical methods revealed a correlation between the concentrations of amphetamine detected with CEDIA (Fig. 2) and those measured with the reference technique Liquid Chromatography with tandem mass spectrometry (LC-MS/MS). None of the analysed samples was a false positive, which indicates the very high specificity of CEDIA. The level of $10 \mathrm{ng} / \mathrm{mL}$ was adopted as the cut-off point, and even at low concentrations of the analyte, no interference was observed that would cause false positive results.

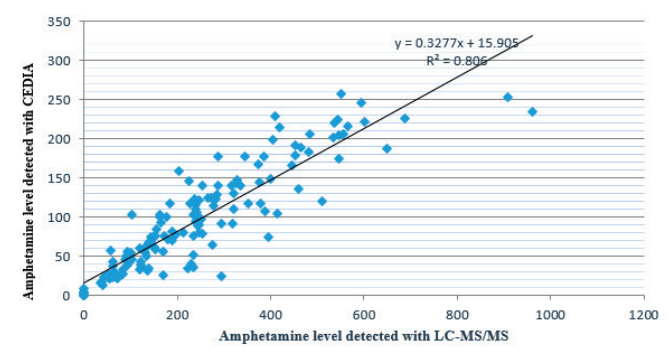

FIGURE 2. Correlation between amphetamine concentrations ( $\mathrm{ng} / \mathrm{mL}$ ) detected with CEDIA and LC-MS/MS

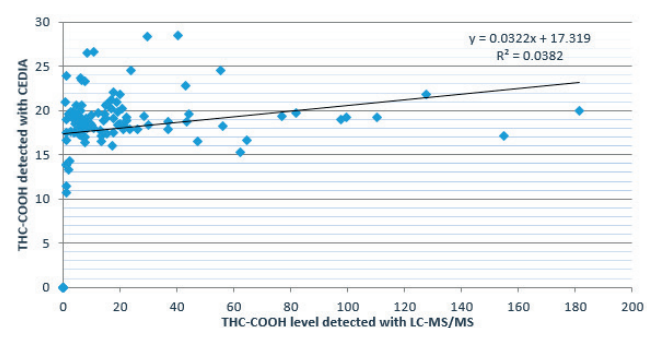

FIGURE 3. Correlation between THC-COOH concentrations $(\mathrm{ng} / \mathrm{mL})$ detected with CEDIA and LC-MS/M

Analyses aimed at the detection of the THC metabolite (THC$\mathrm{COOH}$ - Figure 3 - revealed no linearity between values measured with the 2 analytical techniques. The highest concentrations measured with CEDIA were in the range $25-30 \mathrm{ng} / \mathrm{mL}$, while THC-COOH concentrations detected using the reference technique were much higher.

Like with the amphetamine concentrations, CEDIA provided no false positive results for THC-COOH, even at low concentrations of the analyte (the cut-off point for THC-COOH was $9 \mathrm{ng} / \mathrm{mL}$ ). Therefore, CEDIA lacks the analytical linearity to measure the concentration of THC-COOH, and can only be used for qualitative screening (positive/negative result for THC-COOH). The lack of linearity derives from the fact, that CEDIA is able to detect all the cannabinols contained in the plant material that are inhaled during smoking, whereas the LC-MS/MS method detects only one structural isomer, 11-nor9-carboxy- $\Delta$ 9-tetrahydrocannabinol. The THC-COOH concentration, according to the CEDIA assay, was higher than that measured with the LC/MS-MS method. One potential explanation for this would be low substrate concentration relative to analyte concentration in the immunoassay reaction (Tab. 1). 
TABLE 1. Descriptive statistics of CEDIA and LC-MS/MS methods

\begin{tabular}{lcccc} 
& \multicolumn{2}{c}{ THC-COOH } & \multicolumn{2}{c}{ Amphetamine } \\
\cline { 2 - 5 } & CEDIA & LC-MS/MS & CEDIA & LC-MS/MS \\
\hline Number of tests & 108 & 108 & 141 & 141 \\
\hline Mean & 18.01 & 21.66 & 96.63 & 246.31 \\
\hline Median & 18.76 & 10.1 & 84.75 & 228.1 \\
\hline Maximum & 28.54 & 181.4 & 257.31 & 962 \\
\hline Minimum & 0 & 0 & 0 & 0 \\
\hline Positive results & 102 & 102 & 132 & 132 \\
\hline Negative results & 6 & 6 & 9 & 9 \\
\hline Standard deviation & 5.19 & 34.54 & 66.22 & 181.42 \\
\hline Coefficient of variation & 0.28 & 1.45 & 0.68 & 0.73 \\
\hline
\end{tabular}

TABLE 2. True and negative results for THC-COOH (CEDIA cut-off $9 \mathrm{ng} / \mathrm{mL}$ )

\begin{tabular}{lll} 
& LC/MS-MS positive & LC/MS-MS negative \\
\hline $\begin{array}{l}\text { Positive Test Result } \\
\text { (CEDIA) }\end{array}$ & true & false \\
\hline pogative Test Result -102 & false & positive -0 \\
(CEDIA) & negative -0 & true \\
\hline
\end{tabular}

TABLE 3. True and negative results for amphetamine (CEDIA cut-off $10 \mathrm{ng} / \mathrm{mL}$ ) LC/MS-MS positive LC/MS-MS negative

\begin{tabular}{lll}
\hline $\begin{array}{l}\text { Positive Test Result } \\
\text { (CEDIA) }\end{array}$ & $\begin{array}{l}\text { true } \\
\text { positive }-132\end{array}$ & $\begin{array}{l}\text { false } \\
\text { positive }-0\end{array}$ \\
\hline $\begin{array}{l}\text { Negative Test Result } \\
\text { (CEDIA) }\end{array}$ & false & true \\
negative -0 & negative -9 \\
\hline
\end{tabular}

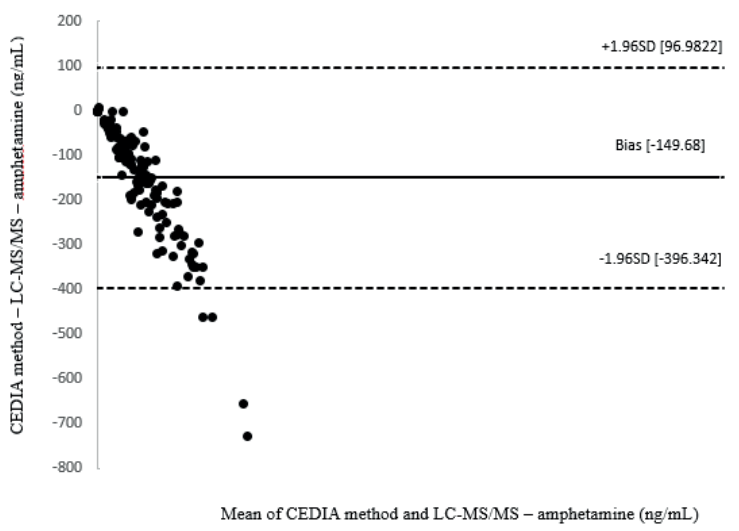

FIGURE 4. Agreement between 2 amphetamine measurements: CEDIA and LC-MS/MS (Bland-Altman plot)

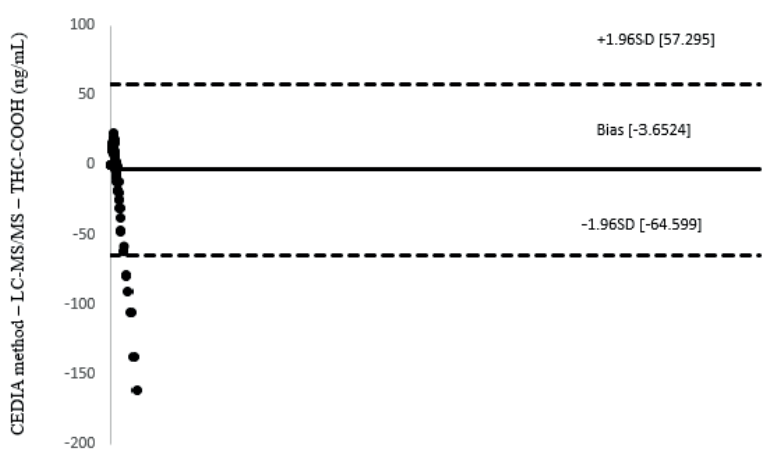

Mean of CEDIA method and LC-MS/MS - THC-COOH $(\mathrm{ng} / \mathrm{mL})$

FIGURE 5. Agreement between $2 \mathrm{THC}-\mathrm{COOH}$ measurements: CEDIA and LC-MS/ MS (Bland-Altman plot)
The sensitivity and specificity calculated for the manufacturer defined cut-off level in CEDIA method was $100 \%$ (Tab. 2 and 3). For completeness, it should be mentioned that as LC-MS/ MS is a quantitative method, cut off points do not exist, but the limit of detection for amphetamine was $1 \mathrm{ng} / \mathrm{mL}$ and for 11-nor-9-carboxy- $\Delta$ 9-tetrahydrocannabinol was $0.5 \mathrm{ng} / \mathrm{mL}$.

The Bland-Altman analysis showed a mean bias for amphetamine of -149.68 , which is not acceptable from a clinical and forensic point of view. Therefore the CEDIA test would not be able to be used as a quantitative method of testing the concentration of amphetamine. The point distribution in the BlandAltman plot for THC-COOH also shows the lack of ability of the CEDIA test as a quantitative method (Fig. 4 and 5).

Significantly, some of the samples tested in our study showed partial haemolysis induced by various factors at the pre-analytical stage. Despite this, no false positive results were found even in significantly degraded blood samples. This is particularly important when the biological material is collected by services other than the testing laboratory and delivered at a different time to the forensic laboratory by the authority ordering analysis. In such cases it is usually impossible to resample material that was affected by haemolysis. On the other hand, re-sampling of the material at a later time has a negative effect on forensic toxicological investigation and bio-degradation of the analysed substances [13]. It is also important for the practice of law enforcement authorities that samples of saliva which were found positive using immunoassays during routine roadside traffic police checks and subsequently tested negatively with LC-MS (false positive saliva test), were also not a false positive when blood from the suspect was tested with CEDIA.

The results of our study suggest that CEDIA provides reliable results in detecting THC-COOH when used as a qualitative technique. On the other hand, there were no false positive results for tested samples at low cut-off values adopted for the analysed xenobiotics, which confirms the high specificity of CEDIA for the detection of both amphetamines and THC-COOH. Available literature provides no information on comparisons between CEDIA and LC-MS/MS for detecting amphetamines and THC-COOH in blood samples. Comparative studies usually concern urine samples, due to the non-invasive and less complicated collection of this material for screening $[14,15]$.

Considering the fact that toxicological forensic tests for the detection of intoxicating and psychotropic substances are done using blood, it is worth conducting research on this biological material. It is also justified to compare the concentrations of other psychoactive drugs, e.g. cocaine and benzodiazepines detected using CEDIA and LC-MS/MS. The detection of these substances, as well as amphetamine and THC-COOH, is of particular importance in the screening of subjects suspected for driving while under the influence of a narcotic drug in the sense of Article 178 a (1) of Kodeks karny (the Polish Criminal Code), or under the influence of psychoactive substance in the sense of Article 87 (1) of Kodeks wykroczen (the Polish Code of Petty Offences) $[16,17]$. Suspects are tested using rapid immunoassays, but their results must be validated by confirmatory blood 
tests. Since confirmatory tests are time-consuming, preliminary qualitative screening for amphetamine and carboxy-THC can be performed in a laboratory using CEDIA, as our study demonstrated. However, the suitability of CEDIA as a screening test for the analysis of biological samples preserved during post-mortem examination for forensic toxicological tests is significantly limited because of the high degradation of the submitted samples. In most cases, it is impossible to isolate serum or plasma from degraded blood samples collected postmortem, which makes CEDIA unfeasible in this type of analysis.

The main limitation of this study is the limited number of negative blood samples, thus this research will certainly be extended in the future, where possible, by including more negative results of amphetamines and THC-COOH.

\section{CONCLUSIONS}

1. This study demonstrates a linearity for amphetamine detection in the CEDIA method.

2. Cloned enzyme donor immmunoassay did not provide false positive results which demonstrates the high specificity of this method.

3. Cloned enzyme donor immmunoassay can be used as qualitative method in forensic and clinical analysis in tests for amphetamine and cannabinoids.

\section{REFERENCES}

1. Koivunen ME, Krogsrud RL. Principles of immunochemical techniques used in clinical laboratory. Lab Medicine 2006;37(8):490-7. doi: 10.1309/ MV9RM1FDLWAUWQ3F

2. Kerrigan S, Philips WH Jr. Comparison of ELISAs for opiates, methamphetamine, cocaine metabolite, benzodiazepines, phencyclidine, and cannabinoids in whole blood and urine. Clin Chem 2001;47(3):540-7.

3. Szukalski B. Analiza środków psychoaktywnych w materiale biologicznym. Alkoh Narkom 2001;14(1):151-63.
4. Neumeister B, Besenthal I, Böhm BO, editors. Diagnostyka laboratoryjna. Poradnik kliniczny. 2nd ed. Wrocław: Elsevier Urban \& Partner; 2013.p. 49-51.

5. Freudenberger K, Hibling U, Gauglitz G. Recent advances in therapeuthic drug monitoring of immmunosupresive drugs. TrAC Trends in Analytical Chemistry 2016;79:257-68. doi: 10.1016/j.trac.2015.11.016.

6. Leclercq M, Soichot M, Delhotal B, Bourgogne E, Gourlain H, Mégarbane B, et al. Interference of metoprolol with amphetamines and MDMA immunoassays. Toxicologie Analytique et Clinique 2019;31(2):S84. doi: doi. org/10.1016/j.toxac.2019.03.135.

7. Saitman A, Park HD, Fitzgerald RL. False-positive interferences of common urine drug screen immunoassays: a review. J Anal Toxicol 2014;38(7):38796. doi: 10.1093/jat/bku075.

8. Rozporządzenie Ministra Zdrowia z dnia 16 lipca 2014 r. w sprawie wykazu środków działających podobnie do alkoholu oraz warunków i sposobu przeprowadzania badań na ich obecność w organizmie (DzU z 2014 r., poz. 948).

9. Ćwiklińska M, Teresiński G, Buszewicz G. Medyczno-sądowe oraz prawnokarne aspekty opiniowania i orzekania w przypadkach intoksykacji środkami odurzającymi i działającymi podobnie do etanolu. Arch Med Sąd 2015;65(2):77-89. doi: 10.5114/amsik.2015.53224.

10. Darragh A, Snyder LM, Ptolemy AS, Melanson S. KIMS, CEDIA, and HSCEDIA immunoassays are inadequatly sensitive for detection of benzodiazepines in urine from patients treated for chronic pains. Pain Physician 2014;17(4):359-66.

11. Loor R, Lingenfelter C, Wason PP, Tang K, Davoudzadeh D. Multiplex assay of amphetamine, methamphetamine, and ecstasy drug using CEDIA technology. J Anal Toxicol 2002;26(5):267-73.

12. Henderson DR, Friedman SB, Harris JD, Manning WB, Zoccoli MA. CEDIA, a new homonogeus immunoassay system. Clin Chem 1986;32(9):1637-41.

13. Wiergowski M, Jankowski Z, Tomczak E, Sein Anand J, Ziółkowski R, Staniszewski J. Propozycja testów oceniających zdolności psychomotoryczne kierowcy oraz protokołu do zastosowania w trakcie pobrania i badania śliny, krwi oraz moczu w przypadku podejrzenia przyjęcia środków działających podobnie do alkoholu. Arch Med Sąd 2012;62:186-97.

14. Bertol E, Vaiano F, Borsotti M, Quercioli M, Mari F. Comparison of immunoassay screening tests and LC-MS-MS for urine detection of benzodiazepines and their metabolites: results of a national proficiency test. J Anal Toxicol 2013;37(9):659-64. doi: 10.1093/jat/bkt063.

15. Köhler KM, Hammer R, Riedy K, Auwärter V, Neukamm MA. Evaluation of CEDIA and DRI drugs of abuse immunoassays for urine screening on a Thermo Indiko Plus Analyzer. J Clin Lab Anal 2017;31(1):e22021. doi: 10.1002/jcla.22021.

16. Ustawa z dnia 6 czerwca 1997 r. Kodeks karny (DzU z 1997 r., nr 88, poz. 553).

17. Ustawa z dnia 20 maja 1971 r. Kodeks wykroczeń (DzU z 1971 r., nr 12, poz. 114). 